\title{
TINGKAT KETAHANAN PANGAN RUMAH TANGGA DI DESA TERTINGGAL
}

\author{
Imron Rosyadi dan Didit Purnomo \\ Fakultas Ekonomi Universitas Muhammadiyah Surakarta \\ Jalan A. Yani Tromol Pos 1 Pabelan Kartasura Surakarta 57102 \\ E -mail: didiet_p@yahoo.com
}

Diterima 1 April 2012 / Disetujui 10 September 2012

\begin{abstract}
The purpose of this study was to determine the level of production, availability of food for the community and analyze the level of accessibility of food for households in villages in the district behind Weru Sukoharjo. The method of analysis used in qualitative research is descriptive analytic in order to approach the situation, structure, behavior and performance (SSPP). Use of this approach is based on the consideration of allegations that sensitive (vulnerable) of food a lot happening in the villages left behind. The results of this study indicate that the performance of food production especially rice or rice has increased significantly from year to year, but increased production has not been able to offset the growth in consumption of rice that grows higher than the growth in rice production. This shows that in terms of food availability, food security in the area of research is still very low.
\end{abstract}

Keywords: food security, availabilty of food, accessibility of food, food production

\begin{abstract}
Abstrak: Tujuan dari penelitian ini menentukan tingkat produksi, ketersediaan pangan bagi masyarakat dan menganalisis tingkat aksesibilitas pangan bagi rumah tangga di desa-desa di kabupaten tertinggal Weru Sukoharjo. Metode analisis yang digunakan dalam penelitian kualitatif adalah analisis deskriptif untuk mendekati situasi, struktur, perilaku, dan kinerja (SSPP). Penggunaan pendekatan ini didasarkan pada pertimbangan bahwa tuduhan sensitif (rentan) makanan banyak terjadi di desa-desa tertinggal. Hasil penelitian ini menunjukkan bahwa kinerja produksi pangan khususnya beras atau beras telah meningkat secara signifikan dari tahun ke tahun, namun peningkatan produksi belum mampu mengimbangi pertumbuhan konsumsi beras yang tumbuh lebih tinggi dari pertumbuhan produksi padi. Hal ini menunjukkan bahwa dari segi ketersediaan pangan, ketahanan pangan di daerah penelitian masih sangat rendah.
\end{abstract}

Kata kunci: ketahanan pangan, ketersediaan pangan, aksesibilitas pangan, produksi pangan

\section{PENDAHULUAN}

Krisis pangan telah benar-benar terjadi di berbagai belahan dunia. Hal ini ditandai dengan melonjaknya harga-harga pangan dunia seperti makanan pokok berupa gandum, kedelai, beras, dan jagung. Penurunan pasokan berdampak pada harga pangan di pasar dunia semakin melambung, sehingga mengakibatkan masyarakat miskin harus membayar lebih mahal dibandingkan orang kaya di negara maju.

Departemen Pertanian (1999) telah mene- tapkan isu ketahanan pangan sebagai salah satu fokus utama kebijaksanaan operasional pembangunan pertanian dalam Kabinet Gotong Royong (1999-2004), dan komitmen ini dilanjutkan dalam Kabinet Indonesia Bersatu (2004-2009). Memantapkan ketahanan pangan merupakan prioritas utama dalam pembangunan karena pangan merupakan kebutuhan yang paling dasar bagi sumberdaya manusia suatu bangsa.

Sejarah membuktikan bahwa ketahanan pangan sangat erat kaitannya dengan ketahanan sosial, stabilitas ekonomi, stabilitas politik 
dan keamanan atau ketahanan nasional (Ritonga, 2008; Irianto, 2008). Selain itu, ketahanan pangan dalam arti keterjangkauan pangan juga berkaitan erat dengan upaya peningkatan mutu sumberdaya manusia Indonesia. Tanpa dukungan pangan yang cukup dan bermutu, tidak mungkin dihasilkan sumberdaya manusia yang bermutu, oleh karena itu membangun sistem ketahanan pangan yang kokoh merupakan syarat mutlak bagi pembangunan nasional.

Kejadian rawan pangan dan gizi buruk mempunyai makna politis yang negatif bagi penguasa. Bahkan di beberapa negara berkembang, krisis pangan dapat menjatuhkan pemerintahan yang sedang berkuasa (Ariani et al., 2006). Kejadian rawan pangan di tingkat rumah tangga dengan proporsi cukup besar masih ditemukan di daerah-daerah dengan ketahanan pangan tingkat regional (provinsi) maupun tingkat nasional terjamin (Saliem et al., 2001). Oleh karena itu pencapaian tingkat ketahanan pangan yang mantap di tingkat nasional maupun regional saja tidak cukup. Mantapnya ketahanan pangan tingkat desa dan tingkat rumah tangga serta individu merupakan sasaran pembangunan ketahanan pangan suatu negara.

Pemerintah telah mengeluarkan PP No 68 Tahun 2002 tentang Ketahanan Pangan. Intinya ketahanan pangan sangat penting untuk membentuk manusia Indonesia yang berkualitas, mandiri, dan sejahtera melalui ketersediaan pangan yang cukup, aman, bermutu, bergizi dan beragam serta tersebar merata di seluruh wilayah Indonesia dan terjangkau oleh daya beli masyarakat. Berbekal PP tersebut semestinya, ketahanan pangan menjadi agenda penting bagi pemerintah bersama masyarakat untuk dilaksanakan. Apalagi banyak komoditi penting yang sampai saat ini masih harus impor untuk memenuhi kebutuhan dalam negeri.

Oleh karena itu, membangun kewaspadaan dan atau ketahanan pangan dari strata pemerintahan yang paling rendah yaitu desa (kelurahan) secara bertahap dan konsisten menjadi suatu keniscayaan untuk menjamin tegaknya kedaulatan pangan di tingkat desa dan atau rumah tangga.

Ketahanan pangan merupakan salah satu isu sensitif bagi keamanan suatu bangsa. Secara umum, ketahanan pangan yang rapuh akan memicu terjadinya konflik. Jacques Diouf (2008) selaku Direktur Jenderal Badan Pangan Dunia (FAO), mengatakan bahwa kelangkaan pangan yang disusul melambungnya harga telah memicu kerusuhan, antara lain di Mesir, Kamerun, Haiti, dan Burkina Faso.

Ketersediaan pangan yang cukup secara nasional ternyata tidak menjamin adanya ketahanan pangan tingkat wilayah (regional), pedesaan, serta rumah tangga individu. Hal ini ditunjukkan antara lain dari studi yang dilakukan oleh Saliem et al. (2004). Terkait dengan fakta tersebut maka masalah bagaimana mengelola ketersediaan pangan yang cukup tersebut agar dapat diakses oleh rumah tangga individu di masing-masing wilayah desa merupakan isu menarik untuk ditelaah. Pengelolaan pangan terkait dengan masalah bagaimana mengelola cadangan pangan, dalam hal ini manajemen cadangan pangan merupakan salah satu aspek yang belum banyak dikaji secara baik.

Ketahanan pangan juga merupakan isu sentral yang menjadi domain utama pemerintah kabupaten Sukoharjo, meskipun sudah diketahui publik bahwa Sukoharjo merupakan salah satu lumbung beras nasional atau berhasil sebagai daerah swasembada beras. Hal ini dibuktikan dengan jumlah produksi beras Sukoharjo yang cukup signifikan, yaitu pada posisi April 2006 mencapai 29.352 ton GKG dengan luas lahan panen 4.651 ha. (Pemda Sukoharjo, 2008). Namun bukan berarti kabupaten Sukoharjo telah terbebas dari persoalan rawan pangan dan atau ketahanan pangan. Persoalan ketahanan pangan bagi pemerintah daerah tentunya bukan sekedar terpenuhinya aspek ketersediaan pangan bagi masyarakat (rumah tangga) artinya pemerintah telah mampu menyediakan pangan bagi seluruh anggota masyarakatnya (Nainggolan, 2006), tetapi juga yang jauh lebih penting adalah aspek aksesibilitas (keterjangkauan) masyarakat (rumah tangga) terhadap bahan pangan. Daya beli rumah tangga merupakan faktor yang sangat berpengaruh terhadap keterjangkauan pangan. Sementara, daya beli masyarakat sangat dipengaruhi oleh besarnya pendapatan dan harga komoditas pangan. 
Pertanyaan krusialnya adalah seberapa besar keterjangkauan rumah tangga-rumah tangga (masyarakat) terhadap bahan pangan, khususnya beras di kabupaten Sukoharjo? Total penduduk Sukoharjo pada tahun 2005 sebesar 817.108 jiwa atau 202.930 KK (PNPM, 2008), yang tersebar pada 12 kecamatan, 152 desa dan 17 kelurahan (Pemkab Sukoharjo, 2008). Dari 202.930 KK tersebut terdapat 90.701 KK yang termasuk dalam kategori KK Miskin dengan rincian per-kecamatan yaitu: $10.089 \mathrm{KK}$ di kecamatan Weru; 11.002 KK di kecamatan Polokarto; 6.616 KK di kecamatan Gatak; 7.567 KK di kecamatan; 9.425 KK di kecamatan Tawangsasri; 9.574 KK di kecamatan Sukoharjo; 5.841 KK di kecamatan Nguter; 7.796 KK di kecamatan Bendosari; 8.307 KK di kecamatan Mojolaban; 5.502 di kecamatan Baki; 3.671 KK di kecamatan Grogol dan 5.311 KK di kecamatan Kartasura. Sementara dari 152 desa di kabupaten Sukoharjo terdapat 26 desa tertinggal (PNPM, 2008).

Di daerah penelitian yaitu di kecamatan Weru terdapat lima (5) desa yang termasuk dalam kategori desa tertinggal, yaitu: desa desa Weru, Tegalsari, Alasombo, Karangmojo, dan Karakan serta terdapat 10.089 KK yang termasuk dalam kategori KK miskin. Data-data tersebut secara eksplisit menunjukkan adanya paradoksal bahwa predikat yang disandang kabupaten Sukoharjo sebagai salah satu daerah lumbung pangan nasional dan merupakan salah satu kabupaten di Indonesia yang berhasil swasembada beras, kenyataan di lapangan menunjukkan bahwa aksesibilitas (keterjangkauan) pangan dan atau ketahanan pangan rumah tangga di pedesaan masih sangat rendah. Sehingga dapat dirumuskan masalah sebagai berikut: (1) Mengidentifikasi seberapa besar tingkat produksi dan ketersediaan pangan bagi rumah tangga di desa-desa tertinggal di kecamatan Weru? (2) Mengetahui dan mengidentifikasi seberapa besar tingkat aksesibilitas (keterjangkauan) pangan bagi rumah tangga di desadesa tertinggal di kecamatan Weru?

Secara umum tujuan penelitian ini adalah untuk manganalisis tingkat keterjangkauan pangan dan atau ketahanan pangan rumah tangga di desa tertinggal dalam rangka merumuskan model peran pemerintah desa melalui "lembaga lumbung pangan (LLP)" desa dalam pengelolaan stok (cadangan) pangan di desa-desa tertinggal. Secara rinci tujuan penelitian dirumuskan sebagai berikut: (1) Untuk mengidentifikasi tingkat produksi, ketersediaan pangan bagi masyarakat di desa-desa tertinggal dan (2) Mengetahui dan mengidentifikasi tingkat aksesibilitas (keterjangkauan) pangan bagi rumah tangga di desa-desa tertinggal.

Konsep Ketahanan Pangan. Konsep ketahanan pangan yang disepakati secara internasional dalam World Conference on Human Right 1993 dan World Food Summit 1996, seperti dilaporkan oleh Saliem et al. (2005); adalah kondisi terpenuhinya kebutuhan gizi setiap individu baik dalam jumlah maupun mutu agar dapat hidup aktif dan sehat secara berkesinambungan sesuai dengan budaya setempat. UndangUndang No.7 tahun 1996 tentang pangan menyebutkan bahwa ketahanan pangan merupakan suatu kondisi terpenuhinya pangan bagi rumah tangga yang tercermin dari tersedianya pangan yang cukup, baik dalam jumlah maupun mutunya, aman, merata dan terjangkau. Rusastra et al. (2005) menyebutkan bahwa ketahanan pangan ditentukan secara bersama antara ketersediaan pangan dan akses individu atau rumah tangga untuk mendapatkan pangan yang dibutuhkan.

Purwaningsih (2008) dan Ariani (2006) melaporkan hasil penelitianya bahwa di Indonesia, peningkatan ketahanan pangan merupakan salah satu program utama nasional sejak satu dasawarsa terakhir. Hal ini juga terkait dengan komitmen Indonesia sebagai salah satu penandatangan kesepakatan dalam MDGs yang menegaskan bahwa tahun 2015 setiap negara diharapkan dapat menurunkan kemiskinan dan kelaparan separuh dari kondisi pada tahun 1990. Pada tahun 2004 muncul kembali kasus gizi buruk di provinsi Nusa Tenggara Timur dan Nusa Tenggara Barat, kemudian diikuti oleh provinsi lainnya. Faktor penyebab kerawanan pangan di suatu wilayah dan rumah tangga mempunyai sifat multidimensional, ditentukan oleh berbagai faktor dan melibatkan berbagai sektor. Mengacu pada karakteristik yang beragam tersebut maka pemecahan masa- 
lah kerawanan pangan wilayah dan rumahtangga harus bersifat holistik.

Ketersediaan Pangan. Ketersediaan pangan yang cukup secara nasional ternyata tidak menjamin adanya ketahanan pangan tingkat wilayah (regional), tingkat desa dan rumah tangga individu. Hal ini ditunjukkan antara lain dari studi yang dilakukan oleh Nurmanaf et al (2006). Terkait dengan fakta tersebut maka masalah bagaimana mengelola ketersediaan pangan yang cukup tersebut agar dapat diakses oleh rumah tangga individu di masing-masing wilayah merupakan isu menarik untuk ditelaah. Pengelolaan pangan terkait dengan masalah bagaimana mengelola cadangan pangan, dalam hal ini manajemen cadangan pangan merupakan salah satu aspek yang belum banyak dikaji secara baik (Saliem et al., 2005).

Ketersediaan pangan tingkat nasional dan regional tidak menjamin adanya ketahanan pangan tingkat rumah tangga atau individu. Hal ini karena di samping ketersediaan pangan, ketahanan pangan rumah tangga individu sangat ditentukan pula oleh akses untuk mendapat pangan tersebut. Dalam hal ini tingkat pendapatan dan daya beli merupakan faktor penentu akses rumah tangga terhadap pangan. Selain itu, di tingkat pengambil kebijakan, kejadian rawan pangan antara lain terkait dengan masalah kebijakan stabilitas harga pangan dan manajemen cadangan stok pangan (Irawan et al., 2006).

Lokollo et al., (2007) menunjukkan bahwa adanya gejolak harga pangan (beras) berdampak negatif terhadap daya beli konsumen dan menghambat rumah tangga untuk akses terhadap pangan yang dibutuhkan. Di tingkat produsen (petani), gejolak harga dan turunnya harga gabah pada saat panen raya berdampak menurunkan pendapatan petani yang dapat diartikan pula menurunkan daya beli petani. Dengan demikian ketidakstabilan harga beras berdampak pula terhadap daya beli dan akses terhadap pangan pada petani (khususnya yang berstatus net-consumer).

Keterjangkauan Pangan. Keterjangkauan pangan atau aksesibilitas masyarakat (rumah tangga) terhadap bahan pangan sangat ditentukan oleh daya beli, dan daya beli ini ditentukan oleh besamya pendapatan dan harga komoditas pangan. Pengaruh pendapatan terhadap akses pangan dapat dilihat melalui pengeluaran bahan pangan, yaitu dengan besamya proporsi pengeluaran rumah tangga untuk bahan pangan. Selanjutnya harga pangan berpengaruh terhadap aksesibilitas terhadap bahan pangan melalui daya beli.

(1) Pengeluaran Bahan Pangan. Terdapat hubungan yang negatif antara proporsi pengeluaran bahan pangan dan ketahanan pangan (ditinjau dari akses ke pangan) (Hukum Working 1943, dikutip oleh Pakpahan, dkk., 1993 dalam Rachman, $d k k$., 2002): (a) Semakin besar proporsi pengeluaran rumah tangga untuk bahan pangan, maka akses terhadap bahan pangan adalah rendah. Semakin besar proporsi pengeluaran rumah tangga untuk bahan pangan juga menunjukkan rendahnya kepemilikan bentuk kekayaan lain yang dapat ditukarkan dengan bahan pangan; (b) Semakin kecil proporsi pengeluaran rumah tangga untuk bahan pangan, maka akses terhadap bahan pangan adalah besar, atau menunjukkan semakin tinggi ketahanan pangannya. (c) Semakin kecil proporsi pengeluaran rumah tangga untuk bahan pangan, juga menunjukkan tingginya kepemilikan bentuk kekayaan lain yang dapat ditukarkan dengan bahan pangan; (d) Rumah tangga tahan pangan yaitu bila proporsi pengeluaran pangan rendah (kurang dari 60 persen dari pengeluaran rumah tangga) dan cukup mengkonsumsi energi ( $>80$ persen dari syarat kecukupan energi); (e) Rumah tangga rentan pangan yaitu bila proporsi pengeluaran pangan tinggi (lebih dari 60 persen dari pengeluaran rumah tangga) dan cukup mengkonsumsi energi (>80 persen dari syarat kecukupan energi); (f) Rumah tangga kurang pangan yaitu bila proporsi pengeluaran pangan tinggi (lebih dari 60 persen dari pengeluaran rumah tangga) dan kurang mengkonsumsi energi ( $\leq 80$ persen dari syarat kecukupan energi) dan (g) Rumah tangga rawan pangan yaitu bila proporsi pengeluaran pangan tinggi dan tingkat konsumsi energinya kurang (Milifpk, 2007).

(2) Harga Komoditas Pangan. Harga pangan menentukan daya beli masyarakat terhadap pangan, dan terdapat hubungan negatif 
antara keduanya. Harga yang meningkat (pada pendapatan tetap), maka daya beli menurun, dan sebaliknya apabila harga turun. Dengan demikian stabilitas harga pangan sangat penting untuk menjamin bahwa masyarakat dapat menjangkau kebutuhan pangannya.

Manajemen Cadangan Pangan. Hasil penelitian Saliem et al. (2004); Saliem et al. (2005) tentang kebijakan pengelolaan cadangan pangan dapat dipaparkan sebagai berikut:

(1) Salah satu kekuatan dalam pengembangan cadangan pangan masyarakat adalah tradisi masyarakat petani secara perorangan untuk menyisihkan hasil panennya guna cadangan pangan masih relatif tinggi. Kekuatan lainnya adalah bahwa produksi padi per satuan luas relatif tinggi sehingga memungkinkan masyarakat petani secara perorangan mengalokasikan hasil panennya baik untuk dijual langsung guna mendapatkan uang tunai maupun untuk disimpan sebagai cadangan pangan;

(2) Kelemahan pertama dalam pengembangan cadangan masyarakat adalah bahwa pengembangan cadangan pangan oleh rumah tangga petani secara perorangan membutuhkan ruang khusus dengan ukuran tertentu yang dapat digunakan untuk menyimpan gabah hingga menjelang panen berikutnya yang sulit untuk dipenuhi oleh setiap rumah tangga petani. Kelemahan kedua adalah bahwa tradisi masyarakat petani untuk melakukan cadangan pangan secara kolektif dalam bentuk lumbung pangan cenderung melemah;

(3) Salah satu faktor yang dapat dipandang sebagai peluang atau kesempatan dalam pengembangan cadangan pangan masyarakat adalah bahwa secara empiris masalah pangan bisa terjadi kapan saja baik disebabkan oleh bencana alam (natural disaster) maupun bencana buatan manusia (konflik sosial) (man made disaster). Faktor lainnya yang dapat dianggap sebagai peluang atau kesempatan adalah bahwa pemerintah berkewajiban mendorong keikutsertaan masyarakat dalam penyelenggaraan ketahanan pangan sebagaimana diktum PP Nomor 68 Tahun 2002 tentang Ketahanan Pangan;

(4) Salah satu tantangan atau ancaman dalam pengembangan cadangan masyarakat berupa terciptanya kondisi ekonomi di mana pa- ngan pokok tersedia secara cukup baik jumlah maupun mutunya serta terjangkau daya beli masyarakat seperti terjadi pada paruh kedua jaman Orde Baru. Tantangan atau ancaman lainnya berupa semakin luasnya adopsi kelembagaan sistem panen secara tebasan dengan konsekuensi petani penggarap tidak lagi membawa pulang gabah tetapi uang tunai;

(5) Dalam konteks pengembangan cadangan pangan masyarakat, strategi yang dipilih untuk mewujudkan tersebarnya cadangan pangan di semua komponen masyarakat serta teratasinya masalah pangan secara cepat adalah sebagai berikut. Pertama, melakukan sosialisasi bahwa mengandalkan sepenuhnya pemenuhan kebutuhan pangan pokok lewat pasar bebas adalah riskan karena masalah pangan bisa terjadi kapan saja. Kedua, melakukan sosialisasi bahwa petani produsen juga bertanggungjawab untuk menyelenggarakan cadangan pangan masyarakat. Ketiga, menumbuh kembangkan dan sekaligus memelihara tradisi melakukan cadangan pangan di tingkat rumah tangga secara sendiri-sendiri. Keempat, menumbuhkan motivasi petani produsen agar membiasakan diri untuk melakukan cadangan pangan secara kolektif dengan membangun lumbung pangan. Kelima, mengelola lumbung pangan dengan orientasi usaha sebagai kegiatan ekonomi bukan lagi sebagai kegiatan sosial, sehingga lembaga ini secara bertahap dapat berperan sebagai salah satu sarana kegiatan ekonomi masyarakat di pedesaan dan tumbuh kembali tradisi masyarakat petani melakukan cadangan pangan secara kolektif.

Dalam konteks pengembangan cadangan pangan pemerintah, strategi yang dipilih untuk mewujudkan tersebarnya cadangan pangan di semua lini pemerintahan serta teratasinya masalah pangan secara cepat adalah sebagai berikut. Pertama, melakukan sosialisasi tentang pentingnya tersedianya cadangan pangan di berbagai tingkat pemerintahan maupun di berbagai elemen masyarakat dalam rangka perencanaan dan pelaksanaan program penanggulangan masalah pangan. Kedua, mempertahankan sistem pencadangan pangan beras yang bersifat sentralistik sebagaimana telah dijalankan selama ini oleh pemerintah pusat. Pertim- 
bangan pertama, dalam implementasinya sistem ini tidak membutuhkan banyak koordinasi sehingga untuk mengatasi masalah pangan yang umumnya harus dilaksanakan dengan segera adalah sangat sesuai. Pertimbangan kedua, penerapan sistem bertingkat dua (two-tier system) selama periode tahun 1952-1958 di mana di tingkat pusat dibentuk Yayasan Urusan Bahan Makanan (YUBM) dan di tingkat daerah dibentuk Yayasan Badan Pembelian Padi (YBPP) ternyata dalam prakteknya kedua lembaga ini tidak sinkron. Ketiga, melakukan pembagian peran dalam pencadangan pangan antara pemerintah pusat dan pemda berdasarkan pada jenis bahan pangan pokoknya. Keempat, menggunakan pendekatan desentralistik (bukan terpusat) dalam mekanisme penyaluran stok beras untuk keadaan darurat dengan pertimbangan untuk memperpendek jalur birokrasi sehingga penanggulangan masalah pangan dapat dilakukan dengan lebih cepat. Kelima, melakukan pembagian peran dalam pencadangan pangan beras antara pemerintah pusat dan pemda ditinjau dari jenis stok berasnya.

Peranan Inovasi Teknologi Padi. Upaya peningkatan produktivitas dan produksi padi terus diupayakan terutama dalam upaya memantapkan ketahanan pangan dengan meningkatkan produksi padi 27.687 ton di kabupaten Sukoharjo pada tahun 2007. Dalam upaya pencapaian target tersebut di antaranya dilakukan penggunaan beberapa padi varietas unggul baru (VUB) bersama dengan penerapan Pengelolaan Tanaman Terpadu (PTT) padi di sawah irigasi. Pada musim tanam April-Agustus 2007 (MT II) telah diintroduksikan 6 padi VUB, yaitu Mekongga, Cigeulis, Cibogo, Sunggal, Cisantana dan Pepe di lokasi Prima Tani kabupaten Sukoharjo. Selain menghasilkan padi/gabah untuk konsumsi juga dihasilkan benih padi bersertifikat kelas SS/BP (label ungu) sebanyak 35,60 ton terdiri dari Mekongga 5,90 ton, Cigeulis 9,65, Cibogo 9,18 ton, Sunggal 2.75 ton, Cisantana 4,63 ton dan Pepe 3,50 ton. Sampai saat benih tersebut telah disebarluaskan sebanyak 31,17 ton $(87,55$ persen) ke sepuluh desa di kecamatan Mojolaban, kabupaten Sukoharjo dan akan ditanam pada MT I (Desember 2007Maret 2008) pada lahan sawah irigasi seluas
1.247 ha dan bila semua benih padi (35,60 ton) tersalurkan diprediksi luas tanam padi VUB menjadi sekitar 1.424 ha (asumsi kebutuhan benih: $25 \mathrm{~kg} / \mathrm{ha}$ ). Berdasarkan hasil unit percontohan produktivitas padi VUB berkisar antara 6,17-6,89 ton/ha atau terjadi kenaikkan antara $0,32-1,11$ ton/ha $(0,81$ ton/ha) bila dibandingkan dengan produktivitas IR 64 , sedangkan produktivitas benih padi 5,21 ton/ha. Produksi benih padi VUB dari lokasi Prima menyumbang sekitar 7,95 persen dari kebutuhan benih padi in hibrida dan diprediksi dapat meningkatkan produksi padi sebesar 1.154 ton atau mengkontribusi 4,17 persen dari target produksi padi kabupaten Sukoharjo. Dengan demikian inovasi teknologi padi varietas unggul memegang peranan cukup penting dalam hal peningkatan produktivitas dan produksi padi di lahan sawah irigasi.

\section{METODE PENELITIAN}

Mengingat cakupan ketahanan pangan sangat luas, maka untuk penajaman penelitian, pangan dibatasi pada gabah dan atau beras. Data yang digunakan adalah data sekunder dari pemerintahan desa-desa tertinggal di kabupaten Sukoharjo yang berupa laporan tahunan kepala desa, daftar isian perlombaan desa tingkat kabupaten Sukoharjo 2008, profil desa dan dokumen-dokumen pemerintahan desa yang terkait dengan penelitian ini serta data primer yang dikumpulkan di lokasi penelitian dengan metode purposive sampling yaitu: (1) kuesioner tentang ketahanan pangan rumah tangga di desa-desa tertinggal, meliputi: (i) ketersediaan pangan desa (rumah tangga), (ii) akses pangan desa (rumah tangga) dan produksi pangan desa (rumah tangga); (2) wawancara mendalam kepada masyarakat (petani) dan pemerintah tentang pemanfaatan tanah kas desa.

Informasi kualitatif akan diperoleh dari informan kunci dari aparatur pemerintahan desa, dinas terkait tingkat kabupaten lokasi penelitian dan tokoh masyarakat di daerah penelitian. Metode analisis yang akan digunakan dalam penelitian adalah deskriptif kualitatif (analitis) dalam kerangka pendekatan situasi, struktur, perilaku dan performa (SSPP). Peng- 
gunaan pendekatan ini dasarkan atas pertimbangan performa seperti, belum terwujudnya manajemen cadangan pangan di daerah penelitian; belum eksisnya lembaga lumbung pangan di daerah penelitian; serta adanya dugaan bahwa rawan (rentan) pangan banyak terjadi di desa-desa tertinggal. Variabel-variabel yang digunakan dalam penelitian, dapat definisikan sebagai berikut: (1) Tingkat produksi dan ketersediaan pangan adalah jumlah rata-rata produksi beras per-tahun per-ha dalam dua kali tanam bagi rumah tangga-rumah tangga dan (2) Tingkat aksesibilitas (keterjangkauan) pangan adalah proporsi pengeluaran bahan pangan terhadap pendapatan per-bulan per-rumah tangga di desa-desa tertinggal. Pengukurannya adalah (i) Rumah tangga tahan pangan yaitu bila proporsi pengeluaran pangan rendah (kurang dari 60 persen dari pengeluaran rumah tangga) dan cukup mengkonsumsi energi $(>80$ persen dari syarat kecukupan energi); (ii) $\mathrm{Ru}$ mah tangga rentan pangan yaitu bila proporsi pengeluaran pangan tinggi (lebih dari 60 persen dari pengeluaran rumah tangga) dan cukup mengkonsumsi energi (>80 persen dari syarat kecukupan energi); (iii) Rumah tangga kurang pangan yaitu bila proporsi pengeluaran pangan tinggi (lebih dari 60 persen dari pengeluaran rumah tangga) dan kurang mengkonsumsi energi $\leq 80$ persen dari syarat kecukupan energi) dan (iv) Rumah tangga rawan pangan yaitu bila proporsi pengeluaran pangan tinggi dan tingkat konsumsi energinya kurang. dan (3) Desa tertinggal adalah desa-desa di kecamatan Weru kabupaten Sukoharjo yang dikategorikan oleh PNPM sebagai desa tertinggal yaitu ada 5 Desa: (i) Weru; (ii) Tegalsari; (iii) Alasombo; (iv) Karangmojo dan (v) Karakan.

\section{HASIL DAN PEMBAHASAN}

Kegiatan penelitian ini bermula dari observasi terhadap rumah tangga yang bertempat tinggal menetap di lima (5) desa tertinggal yang berada dalam wilayah kecamatan Weru Kabupaten Sukoharjo, yaitu desa Weru, Tegalsari, Alasombo, Karangmojo, dan Karakan. Keterpilihan desa-desa tersebut sebagai daerah observasi didasarkan atas kriteria-kriteria sebagai desa tertinggal yang sudah ditetapkan oleh PNPM yang berada di wilayah kecamatan Weru kabupaten Sukoharjo. Sehingga keterpilihan desadesa tersebut sebagai objek penelitian, sesuai dengan tujuan yang diinginkan dalam penelitian ini. Observasi terhadap rumah tanggarumah tangga dilakukan dengan metode wawancara untuk mengetahui beberapa hal yang terkait langsung dengan tujuan penelitian ini yaitu: (1) jumlah produksi beras ha-1 dalam satu tahun, (2) rata-rata ketersediaan beras dalam satu tahun, (3) jumlah nilai ( $R p)$ rata-rata pengeluaran untuk bahan pangan dalam satu tahun, (4) jumlah nilai (Rp) rata-rata pendapatan dalam satu tahun.

Setelah data-data tersebut diperoleh atau dikumpulkan, langkah selanjutnya dilakukan pengolahan data untuk mengetahui jumlah rata-rata produksi beras pendapatan dan pengeluaran rumah tangga-rumah tangga di daerah penelitian. Langkah berikutnya adalah menganalisis hasil pengolahan data dengan metode deskriptif-analitik, untuk mendeskripsikan, menjelaskan dan mengidentifikasikan apakah rumah tangga-rumah tangga di daerah penelitian dapat dikategorikan sebagai rumah tangga tahan pangan, rumah tangga rentan pangan, rumah tangga kurang pangan, atau rumah tangga rawan pangan.

\section{Produksi dan Ketersediaan Pangan}

Produksi pangan sangat tergantung pada tingkat produktifitas dan luas areal panen. Komoditas pangan, khususnya beras berdasarkan Tabel 1. menunjukkan bahwa produksi beras cenderung berfluktuatif kecil (tidak signifikan). Produksi beras mencapai puncaknya pada tahun 2009 yaitu dengan total produksi gabah sebesar 51.849 (ribu ton), sedangkan produksi beras setelah dihitung dengan faktor konversi sebesar 32.697 (ribu ton). Sehingga dapat dinyatakan bahwa pertumbuhan produktifitas pangan padi relatif konstan pada periode 20042009. Selanjutnya berdasarkan data yang sama impor beras cenderung menurun, namun dengan angka yang relatif besar serta mencapai puncak-nya pada tahun 2004 yaitu sebesar 5,765 ribu ton. Berdasarkan angka impor yang relatif besar tersebut, Indonesia diperkirakan 
tidak mudah bisa secara konsisten sebagai negara swasembada pangan. Hal ini semakin nyata apabila dikaitkan dengan semakin menyempit-nya luas areal panen yang diakibatkan oleh faktor konversi lahan secara terus-menerus terutama di Jawa. Konversi tersebut dalam bentuk penggunaan lahan persawahan pertanian menjadi lahan non-pertanian, seperti untuk lahan industri, perumahan, dan sarana dan prasanan yang lain. Pengalihan fungsi lahan dari fungsi pertanian menjadi fungsi bangunan menjadi penyebab utama berkurangnya lahan pertanian, yang selanjutnya berdampak pada menurunnya produksi pangan khususnya beras, sementara jumlah penduduk terus meningkat signifikan. Faktor penyebab lain adalah perubahan iklim global yang cenderung destruktif terhadap tanaman padi seperti, serangan wereng secara mendadak serta curah hujan yang terlalu tinggi dan terus menerus

Temuan pada Tabel 1 sejalan dengan hasil penelitian Saifullah (2002) yang menyatakan bahwa selama 10 tahun terakhir ini rata-rata kenaikan produksi pangan hanya sekitar 0,9 persen. Padahal, konsumsi justru naik sekitar 2,5-3 persen. Sedangkan untuk beras, kenaikan produksinya hanya sekitar 1 persen per tahun. Tingkat produktivitas domestik atas sejumlah komoditas pangan malah mengalami stagnasi. Untuk beras, misalnya, stagnan berada pada tingkat 4,3 ton/ha. Di sisi lain, perluasan area komoditas pangan tahun-tahun terakhir juga cenderung turun. Misalnya, 2001 penurunan luas area panen terjadi pada semua komoditas pangan khususnya beras turun 3,2 persen. Setidaknya ada dua penyebab utama mengapa produksi pangan domestik belum mampu mencukupi kebutuhan pangan nasional. Pertama, kon- versi lahan produktif pertanian. Selama 10 tahun terakhir, fenomena alih fungsi (konversi) lahan pertanian tampak nyata terjadi. Untuk areal sawah di Jawa, misalnya, beberapa hasil penelitian menunjukkan dalam satu dekade terakhir rata-rata konversi lahan sawah di Jawa mencapai 13.400 sampai 22.500 hektare (ha) per tahun (Irawan, 2002). Penyusutan lahan persawahan di Jawa disebabkan desakan pertambahan penduduk, perkembangan sektor industri, konversi lahan produktif menjadi realestat, daerah wisata, dan peruntukan lainnya yang saling tumpang-tindih. Hal ini dapat dilihat, misalnya, dari laju konversi lahan pertanian yang cepat. Selama ini kecenderungan konversi lahan yang tinggi terjadi pada lahan-lahan pertanian di sekitar sentra pertumbuhan ekonomi dan industri yang umumnya adalah kota-kota besar di Jawa. Contohnya, laju konversi yang tinggi adalah di sekitar wilayah Jabotabek, Bandung, Semarang, Yogyakarta, Surabaya, dan Malang. Padahal, lahan pertanian produktif pulau Jawa adalah lahan relatif lebih subur yang tentu saja berkontribusi signifikan terhadap produksi pangan nasional. Hasil penelitian Bank Dunia pada 1995 untuk kualitas lahan sawah di Jawa mengatakan setiap pengurangan satu hektare di Jawa diperlukan 2,3 ha sawah di Sumatra, 6 ha di Kalimantan, atau 12 ha sawah di Irian Jaya sebagai pengganti untuk mendapatkan tingkat produksi yang sama. Kedua, sekitar 89,4 persen petani kita tergolong petani guram yang hanya memiliki lahan di bawah 2 ha. Bahkan, sekitar 48,5 persen di antaranya hanya memiliki lahan rata-rata 0,17 ha. Pertanian berskala kecil seperti yang dimiliki petani kita ini memang sangat sulit diharapkan mampu memberikan sumbangan produksi nasional secara besar-besaran.

Tabel 1. Luas Panen, Produksi dan Produktivitas Gabah (Beras) di Indonesia 2004-2009

\begin{tabular}{cccccc}
\hline Tahun & $\begin{array}{c}\text { Luas Panen } \mathbf{( 0 0 0} \\
\text { ha) }\end{array}$ & $\begin{array}{c}\text { Produktivitas } \\
\text { (ton/ha) }\end{array}$ & $\begin{array}{c}\text { Produksi Gabah } \\
\text { (000 ton) }\end{array}$ & $\begin{array}{c}\text { Produksi Beras } \\
\text { (000 ton) }\end{array}$ & $\begin{array}{c}\text { Impor Beras } \\
\text { (000 ton) }\end{array}$ \\
\hline 2004 & 11.613 & 4,17 & 48.472 & $30.537^{*}$ & 5.765 \\
2005 & 11.963 & 4,25 & 50.866 & 31.118 & 4.183 \\
2006 & 11.793 & 4,40 & 51.898 & 32.345 & 1.513 \\
2007 & 11.415 & 4,39 & 50.181 & 31.283 & 1.400 \\
2008 & 11.521 & 4,47 & 51.379 & 32.369 & 3.100 \\
2009 & 11.453 & 4,53 & 51.849 & 32.697 & 2.000 \\
\hline
\end{tabular}

Sumber: Statistik Pertanian, Ditjen Teknis Lingkup Deptan 2004-2009

*Faktor konversi sebesar 0,63 
Tabel 2. Produksi Padi di Kabupaten Sukoharjo Triwulan I 2009

\begin{tabular}{lrrrr}
\hline & Januari & Pebruari & Maret & April \\
\hline Luas Panen (ha) & 1.052 & 2.345 & 10.639 & 4.651 \\
\hline Produksi (ton GKG) & 6.698 & 14.931 & 69.951 & 29.352 \\
\hline
\end{tabular}

Sumber: Dinas Pertanian Kabupaten Sukoharjo

Sebab, secara teoritis pertanian lahan sempit ini produksinya rendah, pendapatannya kecil sehingga tidak dapat menabung. Karena itu, tidak mungkin memperbaiki teknologinya sehingga produktivitas lahannya akan terus rendah. Tesis ini secara sederhana menyatakan tidak mungkin menjaga ketahanan pangan berbasis petani guram. Memang, terminologi ketersediaan pangan yang dirumuskan lembaga pangan dunia, FAO, tidak mensyaratkan suplai pangan domestik harus dari produksi domestik, tetapi bisa juga dari impor. Artinya, suatu Negara tetap terjaga ketahanan pangan kalau ia bisa mengimpor komoditas pangannya dari negara luar, tidak harus komoditas tersebut diproduksi sendiri. Walaupun ketersediaan pangan nasional bisa dicukupi melalui impor, ada hal penting yang harus disadari bahwa mengandalkan impor untuk ketersediaan komoditas pangan domestik, apalagi komoditas pangan strategis, adalah berisiko tinggi dan berbahaya. Sebagai contoh untuk produk beras dan gula. Untuk beras diketahui bahwa penawaran dan harganya di pasar internasional sangat tidak stabil. Hal ini bukan saja disebabkan kondisi iklim dan lingkungan, melainkan lebih dari itu, pasar beras internasional bersifat oligopoli. Pasar beras internasional didominasi enam negara pengekspor beras, yakni Thailand, AS, Vietnam, Myanmar, Pakistan, dan China. Di samping itu, pasar beras internasional dikenal sebagai 'pasar yang tipis'. Karena, 96 persen beras yang diproduksi negara-negara produsen beras dikonsumsi negara-negara itu sendiri. Hanya sekitar 4 persen yang diperdagangkan di pasar internasional. Sebagaimana halnya beras, pasar gula dunia pun bersifat oligopoli. Suplai gula dunia dikuasai tujuh konglomerat gula dunia, dengan sekitar 83 persen perdagangan gula dunia ada di tangan mereka. Dapat dibayangkan, kalau kita mengandalkan penyediaan pangan strategis tersebut dari impor maka cepat atau lambat yang terjadi adalah rawan pangan. Bahkan, lebih dari itu, rawan sosial politik dan hankam.

Selanjutnya untuk memcermati dan menganalisis produksi dan ketersediaan pangan di kabupaten Sukoharjo, khususnya di daerah tertinggal di kecamatan Weru dapat dilihat pada Tabel 2 dan Tabel 3. Tabel tersebut menunjukan bahwa luas panen dan produksi padi di kabupaten Sukoharjo pada triwulan I cenderung berfluktuatif dan mencapai puncak-nya pada bulan Maret 2009, yaitu luas panen sebesar 10.639 ha dengan hasil panen sebesar 69.951 ton GKG.

Sementara jika pertumbuhan produksi beras tersebut dibandingkan dengan pertumbuhan konsumsi beras, sebagaimana tampak pada Tabel 3. menunjukkan bahwa pertumbuhan konsumsi beras lebih tinggi dari pertumbuhan produksi beras, artinya ada ketidakseimbangan antara supply dan demand di daerah penelitian. Selanjutnya rasio produksi beras terhadap konsumsi beras, sebagaimana nampak pada tabel yang sama memperlihatkan bahwa pada triwulan pertama tahun 2009 rasio tersebut di bawah 100 persen, artinya kekurangan dari 100 persen

Tabel 3. Produksi Beras di 5 Desa Tertinggal Kecamatan Weru Kabupaten Sukoharjo Triwulan I 2009 (dalam persen)

\begin{tabular}{lrrrr}
\hline & \multirow{2}{*}{ Januari } & \multirow{2}{*}{ Pebruari } & \multirow{2}{*}{ Maret } & April \\
\hline Pertumbuhan produksi & 5,14 & 4,35 & 3,15 & 4,65 \\
\hline Pertumbuhan konsumsi beras & 2,96 & 5.65 & 6.95 & 7,35 \\
\hline Rata2 Pangsa Produksi thdp konsumsi & 95,50 & 94.931 & 69.951 & 29.352 \\
\hline
\end{tabular}

Sumber: Dinas Pertanian Kabupaten Sukoharjo 
dilakukan dengan mendatangkan komoditas beras dari daerah lain, karena di daerah setempat (lokasi penelitian) tidak mampu menyuplai seluruh kebutuhan beras bagi masyarakat di desa tertinggal yang ada di kecamatan Weru.

Pada triwulan I bulan April 2009 menunjukkan bahwa pertumbuhan konsumsi beras jauh melampaui pertumbuhan produksinya, yaitu konsumsi beras tumbuh sebesar 7,35 persen, sementara produksi beras hanya tumbuh sebesar 4,65 persen. Selanjutnya pada periode yang sama desa-desa tertinggal di kecamatan Weru, hanya mampu menyuplai kebutuhan beras sebesar 29,35 persen dari total kebutuhan komoditas beras, sedangkan sisanya sebesar 70,65 persen kebutuhan beras diperoleh bukan dari lahan pertanian di daerah penelitian.

Tabel 4 menunjukkan kinerja produktifitas pangan khususnya beras di 5 desa tertinggal di Kecamatan Weru pada periode 2004-2009. Produksi gabah atau beras dari tahun-tahun menunjukkan peningkatan yaitu mencapai puncaknya pada tahun 2009 dengan nilai ouput produksi 160,707 ton gabah atau 101,245 ton beras dengan luas panen yang cenderung fluktuatif tidak signifikan. Sehingga dapat disimpulkan bahwa produksi pangan (beras) di desadesa tertinggal di kecamatatan Weru, secara statistik terus mengalami peningkatan namun belum mampu meyediakan kebutuhan pangan bagi seluruh masyarakat atau dengan kalimat lain ketersediaan pangan di daerah penelitian belum bisa menjamin ketersediaan pangan yang cukup bagi masyarakat di daerah penelitian.

\section{Aksesibilitas (Keterjangkauan) Pangan}

Kerterjangkauan secara ekonomi adalah faktor penting untuk melihat ketahanan pangan masyarakat dari sudut kemampuan daya beli masyarakat terhadap pangan. Ada tiga kelompok masyarakat dilihat dari keterjangkauan terhadap pangan Pertama, kelompok berpendapatan tinggi yang mampu membeli pangan pada situasi harga pasar apa pun. Kepada kelompok ini memang kebutuhan pangan mereka diserahkan sepenuhnya kepada mekanisme pasar. Kedua, kelompok berpenghasilan sedang yang mampu membeli pangan pada harga pasar saat kondisi normal. Namun, akses kelompok ini akan melemah apabila terjadi gejolak harga. Dalam kelompok ini ada yang tergolong miskin sementara (transient poverty) yang biasanya rentan pada masa krisis, tapi segera pulih setelah krisis berlalu. Ketiga, kelompok masyarakat yang berpenghasilan rendah dan berada pada kondisi miskin kronis (chronics poverty). Masyarakat pada kelompok ini tidak mampu membeli pangan pada harga pasar dalam kondisi normal sekalipun. Dampak krisis ekonomi sejak pertengahan 1997 sampai saat ini menyebabkan jumlah orang yang masuk ke dalam kelompok kedua dan ketiga meningkat pesat dibanding sebelum krisis. Diketahui bahwa tingkat kemiskinan naik 66 persen dari 22,5 juta orang 1996 (sebelum krisis) menjadi 37,5 juta pada 1999. Apabila digunakan data Badan Koordinasi Keluarga Berencana Nasional 2001, jumlah keluarga prasejahtera dan sejahtera I yang dikategorikan masuk dalam kelompok miskin bahkan lebih besar lagi, yakni mencapai 14,7 juta jiwa. Informasi ini menunjukkan dari aspek keterjang-kauan pangan, cukup signifikan rakyat Indonesia yang rentan ketahanan pangannya.

Konsep ketahanan pangan didasarkan atas akses individu atau rumahtangga terhadap pa-

Tabel 4. Rata-rata Luas Panen, Produksi dan Produktivitas Gabah (Beras) Periode 2004-2009 di 5 Desa Tertinggal di Kecamatan Weru

\begin{tabular}{ccccc}
\hline Tahun & Luas Panen (ha) & Produktivitas (ton/ha) & Produksi Gabah (ton) & Produksi Beras (ton) \\
\hline 2004 & 35,512 & 3,22 & 114,348 & $72,039^{*}$ \\
2005 & 34,282 & 3,25 & 111,416 & 70,192 \\
2006 & 33,176 & 3,30 & 109,481 & 68,973 \\
2007 & 36,798 & 3,39 & 124,745 & 78,589 \\
2008 & 46,216 & 3,42 & 158,058 & 99,576 \\
2009 & 45,526 & 3,53 & 160,707 & 101,245 \\
\hline
\end{tabular}

Sumber: Diolah Dari Dinas Pertanian Kabupaten Sukoharjo

Catatan: *Faktor konversi sebesar 0,63 
Tabel 5. Pengeluaran Rata-Rata per-Bulan/Kapita Menurut Harga yang Berlaku Periode 2004-2009 di 5 Desa Tertinggal di Kecamatan Weru

\begin{tabular}{|c|c|c|c|c|c|c|}
\hline Keterangan & 2004 & 2005 & 2006 & 2007 & 2008 & 2009 \\
\hline $\begin{array}{ll}\text { I. } & \text { Makanan } \\
& (\mathrm{Rp} .) \\
& (\%)\end{array}$ & $\begin{array}{r}195.800 \\
70,55\end{array}$ & $\begin{array}{r}215.000 \\
74,66\end{array}$ & $\begin{array}{r}345.750 \\
76,76\end{array}$ & $\begin{array}{r}532.600 \\
78,90\end{array}$ & $\begin{array}{r}655.750 \\
79,65\end{array}$ & $\begin{array}{r}856.900 \\
80,67\end{array}$ \\
\hline $\begin{array}{l}\text { II. Bukan Makanan } \\
(\mathrm{Rp}) \\
(\%)\end{array}$ & $\begin{array}{r}81.734 \\
29,45\end{array}$ & $\begin{array}{r}72.972 \\
25,34\end{array}$ & $\begin{array}{r}104.680 \\
23,24\end{array}$ & $\begin{array}{r}115.688 \\
21,10\end{array}$ & $\begin{array}{r}167.539 \\
20,35\end{array}$ & $\begin{array}{r}205.329 \\
19,33\end{array}$ \\
\hline
\end{tabular}

Sumber: Diolah Dari Dinas Pertanian Kabupaten Sukoharjo

ngan. Semakin tinggi akses suatu rumah tangga terhadap pangan maka semakin tinggi ketahanan pangan. Kemampuan rumahtangga memiliki akses terhadap pangan tercermin dalam pangsa pengeluaran untuk membeli makanan. Hubungan antara pangsa pengeluaran pangan dan total pengeluaran rumah tangga dikenal dengan hukum working. Hukum tersebut menyatakan pangsa pengeluaran pangan memiliki hubungan yang negatif dengan total pengeluaran rumah tangga. Dengan kata lain, pangsa pengeluaran pangan menurun secara proporsional sesuai dengan logaritma kenaikan pengeluaran rumah tangga. Pengeluaran rumah tangga itu sering digunakan sebagai proksi dari tingkat pendapatan rumah tangga. Hal tersebut memperlihatkan ketahanan pangan memiliki hubungan yang negatif dengan pangsa pengeluaran pangan. Jadi, semakin besar pangsa pengeluaran pangan suatu rumah tangga maka semakin rendah ketahanan pangan rumah tangga tersebut, demikian pula sebaliknya.

Tabel 5 mendeskripsikan share antara pengeluaran rumah tangga untuk bahan makanan dengan pengeluaran rumah tangga untuk bahan bukan makanan. Pada kurun waktu 20042009 memperlihatkan bahwa pengeluaran rumah tangga untuk bahan makanan mengalami trend peningkatan yang cukup signifikan, yaitu dari rata-rata Rp655.750 per-bulan/ kapita pada tahun 2008 meningkat menjadi Rp856.900 perbulan/perkapita pada tahun 2009.

Sementara itu apabila dicermati pada share pengeluaran rumah tangga, memperlihatkan bahwa proporsi pengeluaran rumah tangga untuk bahan pangan dari tahun ke tahun terus mengalami peningkatan yang cukup signifkan, yang puncaknya pada tahun 2009 sebesar 80,67 persen untuk bahan makanan dan 19,33 persen untuk bahan bukan makanan. Hal ini mendeskripsikan bahwa proporsi pengeluaran rumah tangga untuk bahan makanan jauh lebih tinggi daripada pengeluaran rumah tangga untuk bahan bukan pangan. Tabel 5 juga menunjukkan bahwa proporsi pengeluaran rumah tangga untuk bahan pangan selama periode 2004-2009 lebih besar dari 60 persen interpretasinya bahwa akses masyarakat di daerah penelitian terhadap bahan pangan adalah rendah, sehingga dapat disimpulkan bahwa masyarakat di daerah penelitian memiliki ketahanan pangan yang rendah atau rumah tangga rentan terhadap pangan

\section{SIMPULAN}

Mengacu pada tujuan penelitian ini dan jawaban atas tujuan penelitian yang dibahas dalam bab "pembahasan hasil" dapat diambil beberapa kesimpulan bahwa desa-desa tertinggal di kecamatan Weru (daerah penelitian) dalam kondisi dan situasi sebagai berikut: (1) Kinerja produksi pangan khusus-nya gabah atau beras mengalami peningkatan yang signifikan dari tahun ke tahun, namun peningkatan produksi tersebut belum mampu mengimbangi pertumbuhan konsumsi beras yang tumbuh lebih tinggi dari perumbuhan produksi beras. Hal ini menunjukkan bahwa dilihat dari aspek ketersedian pangan, ketahanan pangan di daerah penelitian masih sangat rendah, karena tidak mampu menyediakan pangan bagi seluruh masyarakat di daerah penelitian; (2) Proporsi (share) pengeluaran rumah tangga untuk kebutuhan pangan jauh lebih tinggi dari pe- 
ngeluaran rumah tangga untuk kebutuhan bahan bukan pangan, yaitu rata-rata 78 persen untuk kebutuhan bahan pangan, sedangkan 22 persen untuk kebutuhan bukan pangan. Hal ini menunjukan bahwa dilihat dari komponen keterjangkauan pangan, masyarakat (rumah tangga) di daerah penelitian, masuk dalam kategori rentan terhadap pangan.

Keterbatasan Penelitian. Peneliti tidak berpretensi bahwa penelitian tentang ketahanan pangan ini, telah menghasilkan output penelitian yang sempurna ke-akurasian-nya, namun ada beberapa keterbatasan yang bisa diidentifikasi yaitu: (1) Penelitian tidak memasukkan variabel "kualitas makanan dan nutrisi" yang merupakan komponen penting dalam mengidentifikasi ketahanan pangan rumah tangga; (2) Penelitian yang dilakukan hanya sebatas identifikasi ketahanan pangan, belum bisa mengetahui faktor-faktor apa saja yang mempengaruhi ketahanan pangan rumah tangga di daerah penelitian; dan (3) Hasil penelitian belum mendeskripsikan bagaimana memformulasikan sebuah model pengelolaan ketahanan pangan untuk mengatasi kerentanan rumah tangga terhadap pangan di daerah penelitian.

Saran penelitian selanjutnya. Berdasarkan beberapa keterbatasan yang telah diidentifikasikan tersebut, peneliti mengharapkan kepada peneliti berikutnya untuk menyempurnakan penelitian ini dengan mempertimbangkan beberapa hal sebagai berikut: (1) Memasukkan variabel "kualitas makanan dan nutrisi" dalam analisis tentang ketahanan pangan; (2) Kemungkinan dimasukkan analisis statistik (model regresi) dalam desain penelitian berikutnya sehingga mendapatkan hasil yang lebih akurat; dan (3) Proses dan prosedur penelitian diarahkan untuk hasil temuan bagaimana memformulasikan sebuah model pengelolaan ketahanan pangan untuk mengatasi kerentanan rumah tangga terhadap pangan di daerah penelitian.

\section{Ucapan Terimakasih}

Ucapan terima kasih kami sampaikan kepada LPPM-UMS yang telah memberikan kesempatan dan menyetujui pelaksanaan penelitian ini dengan sumber pembiayaan dari LPPM. Kepada para reviewer dari Fakultas Ekonomi kami ucapkan terimakasih atas seluruh masukan dan perbaikan laporan penelitian ini. Tidak lupa juga kami sampaikan terima kasih kepada rekan-rekan pengkaji pendukung yang telah memberikan kritik, usul perbaikan konstruktif untuk penyempurnaan laporan penelitian ini.

\section{DAFTAR PUSTAKA}

Ariani, M., Saliem H.P., Hardoko G.S. dan Purwantini, T.B. 2006. “Analisis Wilayah Rawan Pangan dan Rawan Gizi Kronis serta Alternatif Penanggulangannya". Laporan Akhir Penelitian. Jakarta: PSEKPBadan Penelitian dan Pengembangan Pertanian, Departemen Pertanian.

Basuno, E., Suhaeti, R.N., Budi, G.S., Iqbal, M. dan Suradisastra, K. 2006. Kaji Tindak (Action Research) Pemberdayaan Masyarakat Pertanian Daerah Tertinggal (Tahap II), Laporan Akhir Penelitian, PSEKP-Badan Jakarta: Penelitian dan Pengembangan Pertanian, Departemen Pertanian.

Departemen Pertanian. 1999. Ketahanan Pangan dan Kebijaksanaan Operasional Pembangunan Pertanian. Jakarta: Departemen Pertanian.

Griffin, W.G. 2004. Manajemen. Jakarta: Penerbit Erlangga.

Ilham, N. 2007. Analisis profil Petani dan Pertanian Indonesia. Laporan Akhir Penelitian. PSEKP-Badan Penelitian dan Pengembangan Pertanian. Jakarta: Departemen Pertanian.

Irawan, B., Simatupang, P., Sugiarto, Supadi, Agustin N.K., Sinuraya, J.F. 2006. Panel Petani Nasional (PATANAS): Analisis Indikator Pembangunan Pertanian dan Pedesaan. Laporan Akhir Penelitian. PSEKPBadan Penelitian dan Pengembangan Pertanian. Jakarta: Departemen Pertanian.

Irianto, G. 2008. Menyelesaikan Konflik Pangan. Opini Republika. Jakarta: PT Republika Media Mandiri. 
Lakollo, E.M., Rusastra, I.W., Saliem H.P., Supriyati, Friyanto, S., dan Budi, G.S. 2007. Dinamika Sosial Ekonomi Pedesaan: Analisis Perbandingan AntarSensus Pertanian. Laporan Akhir Penelitian. Jakarta: PSEKP-Badan Penelitian dan Pengembangan Pertanian Departemen Pertanian.

Mariyono, J. 2006. Spatial and Temporal Analysis of Technical Efficiency in Indonesian Rice Agriculture with Two Alternative Model Specifications. Jurnal Empirika, 19 (2): 135-153. Surakarta: BPPE Fakultas Ekonomi UMS.

Nurmanaf, A.R., Sugiarto, Julin, A., Supadi, Agustin, N.K., Sinuraya, J.F., dan Zakaria A.K. 2005. "Panel Petani Nasional (PATANAS), Dinamika Sosial Ekonomi Rumah Tangga dan Masyarakat Pedesaan: Analisis Profitabilitas Usahatani dan Dinamika Harga dan Upah Pertanian". Laporan Akhir Penelitian. Jakarta: PSEKP-Badan Penelitian dan Pengembangan Pertanian. Departemen, Pertanian.

Pemerintah Desa Pabelan. 2008. Laporan Tahunan Kades". Unpublished

Pemerintah Desa Pabelan. 2008. Daftar Isian dalam Rangka Perlombaan Desa. Unpublished arsip.

Purwaningsih, Yunastiti. 2008. Ketahanan Pangan: Situasi, Permasalahan, Kebijakan dan Pemberdayaan Masyarakat. Jurnal Ekonomi Pembangunan. Vol. 9 No.1 Hal 1-27.

Sayaka, B., Ariani M., Siregar M., Supriadi, H., Ariningsih, E., Rahmanto, B., Asikin, A. 2005. Analisis Pengembangan Agroindustri Berbasis Pangan Lokal Dalam Meningkatkan Keanekaragaman Pangan dan Pengembangan Ekonomi Pedesaan". Laporan Akhir Penelitian. Jakarta: PSEKP-Badan Penelitian dan Pengembangan Pertanian Departemen Pertanian.

Saliem, H.P., Purwoto, A., Hardono, G.S., Purwantini, T.B., Supriyatna, Y., Marisa, Y. dan Waluyo. 2005. Manajemen Ketahanan Pangan Era Otonomi Daerah dan Perum Bulog. Jakarta: PSEKP-Badan Penelitian dan Pengembangan Pertanian, Departemen Pertanian.

Ritonga, R. 2008. Bukan Sekedar Ketahanan Pangan. Opini Republika. Jakarta: PT Republika Media Mandiri.

Rusastra I. W., Noekman K.M., Supriyati, Erma, S., Elizabeth, R., dan Suryadi, M. 2005. Analisis Ekonomi Ketenagakerjaan Sektor Pertanian dan Pedesaan di Indonesia. Jakarta: PSEKP-Badan Penelitian dan Pengembangan Pertanian, Departemen Pertanian. 